\title{
Consumer Behavior and Halal Cosmetic Product: Evidence in Palembang City
}

\author{
Retno Senjawati ${ }^{{ }^{*}}$, Suhel ${ }^{2}$, Imam Asngari ${ }^{3}$ \\ ${ }^{1-3}$ Faculty Economic, Sriwijaya University (UNSRI), South Sumatera, Indonesia \\ Ilir Barat 1, Palembang, South Sumatera, 30128 \\ E-mail: Senjawatiretno03@gmail.com
}

\begin{abstract}
Purpose: this research is about the impact of the product quality, price, halal labeling, and brand ambassador for the purchasing decision of halal cosmetics product.

Methods: the research samples involves 400 female respondents with age 20-49 based on income category, education and kinds of jobs in Palembang city, analysis using the Logit Analysis Method.

Results: (1) the probability of the dominant factor in affecting the purchasing decision of the halal cosmetics product namely price; (2) the product quality, income, halal labeling, and brand ambassador have positive and significant impact; (3) the price has negative and significant impact for the purchasing decision of the purchasing decision of the cosmetics product.

Conclusions and Relevance: overall, there are five potential factors which affect the purchase of the halal cosmetic product. This important aspect should be attention in the cosmetics halal purchase, because it is not only about the price but also the religiosity aspect such as knowledge, attitude, Islamic brand and subjective norm before deciding to buy the product.
\end{abstract}

Keywords: Islamic Demand, Product Quality, Price, Income, Halal Labeling, Brand Ambassador

Conflict of Interes. The authors declare that there is no Conflict of Interest.

For citation: Retno Senjawati, Suhel, Imam Asngari. Consumer Behavior and Halal Cosmetic Product: Evidence in Palembang City. MIR (Modernizatsiia. Innovatsii. Razvitie) = MIR (Modernization. Innovation. Research). 2020; 11(2):233-242. (In Eng.)

\section{Потребительское поведение в отношении халяльной косметической продукции: ситуация в Палембанге}

\section{Ретно Сенджавати ${ }^{1 *}$, Сухел $^{2}$, Имам Аснгари ${ }^{3}$}

\footnotetext{
1-3 Экономический факультет, Университет Шривиджая (UNSRI), Южная Суматра, Индонезия 30128, Индонезия, Южная Суматра, Палембанг, Илир Барат 1

E-mail: Senjawatiretno03@gmail.com
} 


\begin{abstract}
Аннотация
Цель. Представленная статья посвящена исследованию влияния ряда определенных факторов (качества продукции, цены, маркировки халяль и наличия амбассадора бренда) на решение потребителей о покупке халяльных косметических продуктов.
\end{abstract}

Методы или методология проведения работы. Выборка исследования, проведенного в городе Палембанг (Южная Суматра, Индонезия), включала 400 респондентов женского пола в возрасте от 20 до 49 лет, с учетом их категорий дохода, образования и вида деятельности. Анализ полученных данных выполнен с помощью метода логистической регрессии (логит-модель).

Результаты работы. В ходе проведенного исследования: 1) рассмотрена вероятность доминирующего фактора чены при принятии потребителем решения о покупке косметического продукта халяль; 2) установлено, что качество продукции, доход, наличие маркировки халяль и присутствие амбассадора (посла) бренда оказывают положительное и существенное влияние на выбор потребителей; 3) выявлено, что чена продукции может иметь не столь решающее значение на решение о покупке косметического продукта.

Выводы. В целом, существует пять потенциальных факторов, которые влияют на решение потребителей о покупке халяльной косметической продукции. Этому важному факту следует уделить внимание при продаже косметики халяль, поскольку речь идет не только о ее чене. При принятии потребителями решения о покупке косметических продуктов немаловажную роль играют и другие аспекты - религиозные, такие как знание, отношение и принадлежность бренда к исламским традициям, а также субъективные нормы.

Ключевые слова: исламский спрос, качество продукции, чена, доход, маркировка халяль, амбассадор (посол) бренда Конфликт интересов. Авторы заявляют об отсутствии конфликта интересов.

Для цитирования: Ретно Сенджавати, Сухел, Имам Аснгари. Потребительское поведение в отношении халяльной косметической продукции: ситуация в Палембанге // МИР (Модернизация. Инновации. Развитие). 2020. Т. 11. № 2. С. 233-242

https://doi.org/10.18184/2079-4665.2020.11.2.233-242

(с) Ретно Сенджавати, Сухел, Имам Аснгари, 2020

\section{Introduction}

Islam is a religion which is blessed by Allah SWT, has universal character and be a mercy for the universe. Besides Islam, there are other religions which teach kindness, Based on Wilson (2012), Islam is a outlook of life way, philosophy, religion, and belief system which have cultural sources both evolutioner and revolutioner. It equalizes liberal outlook and conservative (Wilson, 2012). This outlook creates different market segmentation in accordance with normative structure and self efficacy (Ashraf, 2019). Moslems are consumer segment and sub culture like others who need life style, cosmetic and entertainment (Wilson \& Liu, 2010; Wilson, 2012). So as Moslems have uniqueness in assessing a product with Halal Aspect (Abd Rahman et al, 2015). In 2010, Indonesia had the greatest number of Moslem labout 209 million or about 13\% of World Moslems and predicted in 2050, Moslems in Indonesia will be 2,567 million or about 9,3\% of the World Moslem Population) (Pew Research Center, 2019).

Due to the high Moslem Population in Indonesia, the necessary of the halal product will be high as well, therefore, the aim of the halal product is not only focus on foods, but also it can spread into all the products especially the lifestyle necessary of the cosmetics product. The Moslems' expense for the halal cosmetics in Indonesia in 2018 ranked the second globally with the total of the expense for the halal cosmetics as much as \$ 4 Billion, in line with it, the halal pharmacy market value in Indonesia as much as $\$ 5.5$ Billion but about 90 percent of the recent raw materials are imported to supply the cosmetics product (Dinar Standar, 2019). Related to the increasing consumption of the halal cosmetics product as a result of the increased income it has caused most of the Moslems enjoying the abundant imported goods. Nevertheless, the increasing products frequently are not understood. (Hong et al., 2019), thus it makes hesitation about the product halalness, especially, the raw materials which are contained in it, like an extracted enzyme of the pork or alcohol as preservative. It makes cynicism for these brands among the moslem consumers looking for the halal products (Mukhtar \& Butt, 2012). In the Islamic order life, Islam gives the guidances and the comprehensive rules in its correlation with Sharia (syari'ah) in worship and muamalah. Consumption is a part of Muamalah al-iqtishodiyah or economy. Moslems are onliged to consume halal products and Moslems are forbidden to consume illicit products. Related to the preference of the cosmetics consumption of the Moslem population who have the high utility of the halal labeled cosmetics compared with the cosmetics without the halal labeling. Based on the preference, the determination of the halal product is consumers' knowledges and attitudes in choosing the halal product. According to the study result of Abd Rahman et al. (2015) which found that there was correlation between knowledge and attitude. The consumers' knowledge is related to the product quality and the price which is identified 
from company's reputation and the institution of certification (Sayogo, 2018). Commonly, there are several factors of consumers' attitude in determining the halal product purchase such as religiosity, the used halal materials in non-food product, the competitive price, the income, the product availability and the trusted halal certification (Hong et al., 2019). Besides that, from main determination religiosity is seen from the moslem's attitude into the advertisement of the beauty product. (Salam et al., 2019).

Based on the result of the previous research that there was a negative correlation between knowledge and attitude. Nevertheless, the correlation between religiosity and attitude is responded by attitude and both intentions are positive (Abd Rahman et al, 2015). The response is line with several key factors such as product quality, price, income, and Halal Sertification (Hong et al, 2019). However, in advertisement side, it responds negatively in Halal Product Purchase (Jamshidi \& Hussin, 2016). On the contrary to the matter.

Islamic Branding is responded positively and significantly but in must be monitored and it is necessary to increase Islamic Brand Promotion to the appropriate consumers of Islamic Provision.

\section{Literature Review}

Postmodern, Capitalist, and Secular People Era, explicitly issued dam predicted religion in business, especially Islam which is assumed as a taboo. Nevertheless, Moslems give a strong thinking about code of ethics in business practice. That, business is a collective obligation and social which are suitable with law principles, it covers broader aspects of human existence. In line with it, Halal Phenomenon is related to Moslem Life in Islamic Thinking Practice along the development of modern world and globalization. Moreover, the proof about howlslamic Sharia is able to evolve and adapt along with the running time and context. Then, it is necessary to observe the importance of the religion in Moslems'Soul indelibly, when consuming and running business (Wilson, 2014).

Study about correlation between religiosity and treatment product, several findings show that religiosity, attitude, and norm are a valid predictor to decide buying the treatment products and halal cosmetics. Nevertheless, the findings also prove that awareness of treatment product and Halal Cosmetics is still low (Ansari \& Mohammed 2015). But, someone who has higher religiosity level is able to overcome external threat or internal conflict in protecting and preserving image and ego. (Arifin et al., 2016).

The interesting finding shows that most consumers rely halal marketing personality, people's perception and halal certification are the most important in forming religion belief when make a purchasing decision. This finding also shows that consumers are affected by halal marketing and branding practice because it is affected by sale promotion celebrity supports (brand ambassador) (Amin et al., 2014).

Then, referring to the product quality, halal labeling is frequently ignored. Actually, the role of halal logo is a product quality indicator (Anam et al., 2018).

Remembering that this product quality is related to the price and the income as a predictor variable, it is revealed in some previous researches which found that religionity and enhancement of awareness about halal product as influencer to consume personal halal product halal sertification and knowledge (Shahid et al., 2018, Abd Rahman et al., 2015).

Utility Maximization Law explains that consumers choose the product from a seri of available alternatives to maximize utility. Conceptually, the utility comes from the consumer goods. Various consumers tend to obtain various utility level of the same product. Condition shows that factors affecting the satisfaction level are out of the product. There is a difference between consumption attitude in conventional aspect and Islam (Amin et al., 2014), conceptually, research design is created to adapt conceptual frame (Hong et al., 2019) with predictor variable in conventional theory namely price, income and appetite (product quality), while, based on the Islamic Demand Aspect by Al-Ghazali in Karim (2016), Welfare (Maslahah) is a concept covering all human activities and making a close correlation between individual and people. Welfare or Maslahah of the people depends on searching and maintaining 5 basic purposes; (1) Religion (ad-dien), (2) Life or soul (nafs), (3) Family or ancestry (nas), (4) treasure or wealth (maa), and (5) Intelligence or mind (aq). Ghazali emphasized that it is suitable with revelation guidance that human main purpose is to achieve kindness in the world and in the eternity (maslahat al-din wa al-dunya).

Referring to the previous research and theory that individual utility is measured from the religiosity level such as halal certification and the use of Islamic Brand, Thus, this concept will involve product quality, price and income to balance liberal's view and conservative (Wilson, 2012) but it is suitable with Islamic Sharia, that conceptual frame is described as follows (Figure 1).

Correlations between exogenous variable is formed into hypothesis for consumer's testing in the Product Market of the Treatment Product in Palembang City. Thus, in detail it can be description of correlation among available variables. Specifically, the hypothesis which come from the previous research can be summarized in Table 1. 


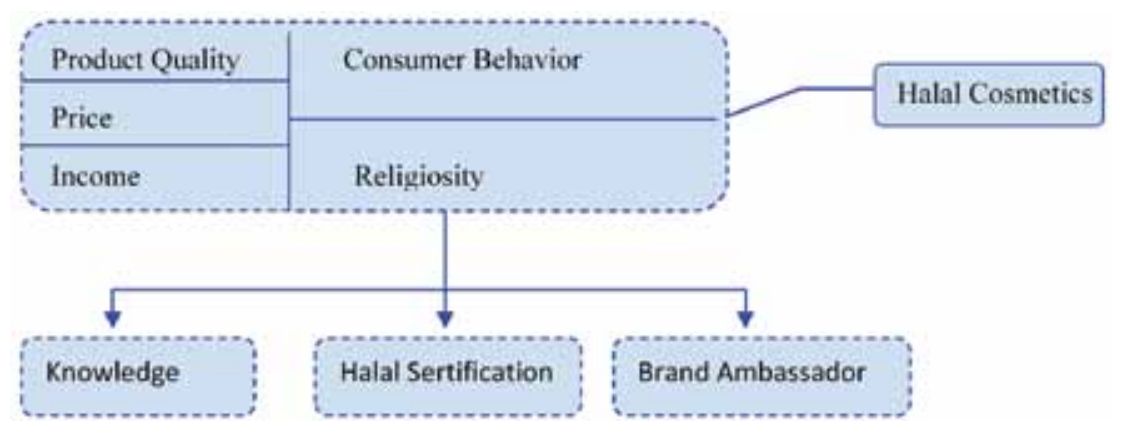

Fig. 1. Determination of Halal Cosmetics Consumer Attitude

Рис. 1. Определение отношения потребителей к халяльной косметике

Hypotheses of previous Research

Гипотезы предыдущих исследований

\begin{tabular}{|c|l|}
\hline No. & \multicolumn{1}{|c|}{ Hypothesis } \\
\hline $\mathrm{H} 1$ & $\begin{array}{l}\text { Product quality has a significant influence of purchasing decision } \\
\text { (Adaptation from research Hong et al., 2019). }\end{array}$ \\
\hline H2 & $\begin{array}{l}\text { Price has a significant influence of purchasing decision } \\
\text { (Adaptation from research Hong et al., 2019). }\end{array}$ \\
\hline H3 & $\begin{array}{l}\text { Income has a significant influence of purchasing decision } \\
\text { (Adaptation from research Hong et al., 2019). }\end{array}$ \\
\hline H4 & $\begin{array}{l}\text { Halal labeling has a significant influence of purchasing decision } \\
\text { (Adaptation from research (Anam et al., 2018; Shahid et al., 2018; Abd Rahmad et al., 2015) }\end{array}$ \\
\hline H5 & $\begin{array}{l}\text { Brand Ambassador Halal has a significant influence of purchasing decision } \\
\text { (Hong et al., 2019; Amin et al., 2014) }\end{array}$ \\
\hline
\end{tabular}

Compiled by the authors.

Составлено авторами.

\section{Research Methodology}

The research uses quantitative data, related to demography social, economy social, involving demography characteristics data, income, product quality, beauty product of consumer's choice, price of beauty product, both cosmetic products, consumer tends to see halal labeling which is available on the back of product package and the purchasing decision which is done by consumers to buy the beauty product in Palembang city.

For validity of data and mitigation of unwanted field condition on survey, this research spread 400 questionnaire with assumption that there are additional questionnaire as much as 5 percent of total sample as many as 384 people who are given to the respondents with female criteria of Data of female population on age 20-49 in Palembang city (Central Bureau of Statistics, Palembang City, 2019). Because of The great number of population, the sample withdrawal uses big sample calculation (Taherdoost, 2016) with the following formula:

$$
n=\frac{N Z^{2} P(1-P)}{N D^{2}+Z^{2} P(1-P)}
$$

Where $Z=1,96$ for the level trust $(\alpha)$ 95\%,

$P=$ proportion (stated as decimal),

$N=$ Population Measurement,

$e=$ error margin.

With using data of total female population, based on the age group 20-49 years old, year 2019 as many as 782.542 inhabitants (Central Bureau of Statistics, Palembang City, 2019), thus, the prediction uses the following equation (1): 


$$
n=\frac{782542(1,96)^{2}(0,50)(1-0,50)}{782542(0,05)^{2}+(1,96)^{2}(0,50)(1-0.50)}
$$

$n=383.97$ or 384 inhabitants.

Proportionally, samples are divided into sub-age category as follows (Table 2).

Table 2

Proportion of Respondents in Research

Доли групп респондентов исследования

\begin{tabular}{|c|c|c|c|}
\hline \multirow{2}{*}{ Age Group } & \multicolumn{3}{|c|}{ Total Female Population (inhabitants) } \\
\cline { 2 - 4 } & \multicolumn{3}{|c|}{ Proportion } \\
\cline { 2 - 4 } & Inhabitant & (\%) & Sample \\
\hline $20-24$ & 150.261 & 19,2 & 73,73 \\
\hline $25-29$ & 138.986 & 17,8 & 68,20 \\
\hline $30-34$ & 133.274 & 17,0 & 65,40 \\
\hline $35-39$ & 129.796 & 16,6 & 63,69 \\
\hline $40-44$ & 122.558 & 15,7 & 60,14 \\
\hline $45-49$ & 107.667 & 13,8 & 52,83 \\
\hline Total & 782.542 & 100,0 & 384,0 \\
\hline
\end{tabular}

Source: Central Bureau of Statistics or Badan Pusat Statistik, Palembang City (Processed Data, 2020)

Источник: Центральное бюро статистики или Badan Pusat Statistik, г. Палембанг (обработанные данные, 2020 г.)

The questionnaires are distributed in 18 sub-district (kecamatan) in Palembang city in age group 20-49 years old which is summarized based on category of income, education and kinds of job. This condition is done to ensure that the respondents have knowledge enough to understand the importance of the materials and able to buy treatment product/cosmetics as a problem in this research.

The Research Instrument is made to facilitate respondents' responses with two response categories. Therefore, Guttman scale is used as variable measurement indicator. To balance analysis because of data prediction is used the analysis tool of regression dummy. Logit model is a variable dependent which has two values or dichotomy characteristic. Logit model adapted from Gujarati (2004) can be applied in buyer decision theory which is measured from consumers' attitude in case buying or not. The first attitude is given score 1 and the second attitude is given score 0 .

$$
P_{i}=E\left(Y=1 \mid X_{i}\right)=\beta_{1}+\beta_{2} X_{i}
$$

Where $X$ is product quality and $Y=$ consumers' decision but condition can represent factors which affect decision of beauty product purchase.

$$
P_{i}=E\left(Y=1 \mid X_{i}\right)=\frac{1}{1+e^{-\left(\beta_{1}+\beta_{2} X_{i}\right)}}
$$

To ease exposition, we write equation 3 as follows:

$$
P_{i}=\frac{1}{1+e^{-z_{i}}}=\frac{e^{z}}{1+e^{z}}
$$

Where $Z_{i}=\beta_{1}+\beta_{2} X_{i}$

Equation (4) is logit function (logistic distribution function). This model verifies that $Z_{i}$ ranges from $-\infty$ until $+\infty, P_{i}$ ranges between 0 and 1 and $P_{i}$ in nonlinear way is related to $Z_{i}$ (namely, $X_{i}$ ), that, is able to choose both of them to buy or not to buy the beauty products.

Nevertheless, it seems in meeting this requirement, there is an estimation trouble because $P_{i}$ is non-linear, not only in $X$ but also in $\beta$ as shown in equation (3), it means that this estimation cannot use OLS Procedure but trouble in equation (3) gets linearization, as follows:

$$
\begin{gathered}
1-P_{i}=\frac{1}{1+e^{-z_{i}}} \\
P_{i}=\frac{P_{i}}{1+P_{i}}=\frac{1+e^{z}}{1+e^{-z_{i}}}=e^{Z}
\end{gathered}
$$

Now, $P_{i} /\left(1-P_{i}\right)$ is only to decide buying, probability ratio that someone is going to buy the product with the probability that someone is not going to buy the product. So, if $P_{i}=0,8$, it means that its chance 
is 4 compares 1, then, someone is going to buy the product. Nevertheless, if using log natural from (6), the estimation result will be more interesting namely it can be seen in equation (7).

$$
L_{i}=\ln \left(\frac{P_{i}}{1+P_{i}}\right)=Z_{i}=\beta_{1}+\beta_{2} X_{i}
$$

$L=\log$ from ratio odds, not only linear in $X$, but also (from viewpoint of estimation) linear with parameter $L$ called Logit, and logit model for equation (8) that model of consumer's attitude theory interpreted in logistic function will form equation (9)

$$
\begin{aligned}
Y_{i} & =\ln \left(\frac{Y 1}{Y 0}\right)=\beta 0+\beta 1 X 1+\beta 2 X 2+ \\
& +\beta 2 X 2+\beta 3 X 3+\beta 4 X 4+\beta 5 X 5
\end{aligned}
$$

Where $Y i=$ Decision of beauty product purchase; $Y 1=$ Buying, $Y 0=$ Not buying; $\beta 0=$ Intercept, $\beta i$ $=$ parameter of model equation coefficient; $X 1=$ Product quality; $X 2=$ Price; $X 3=$ Income; $X 4=$ Halal labeling; X5; Brand Ambassador. Spesifically, the model is going to apply Hosmer and Lemeshow's goodness-of-fit test to check how good the model can be suitable with the series of the observation (Hong et al., 2019).

\section{Results and Discussion}

\section{Statistic Analysis}

Statistic Testing uses an regressive analysis tool of binary logistic to test the determining factors in deciding the cosmetic product purchase with price variable, income, product quality, halal labeling, and brand ambassador, so we can see the following estimation.

\section{Результаты логистической регрессии}

\begin{tabular}{|l|c|c|c|c|c|c|}
\hline \multirow{2}{*}{ Variabel } & B & S.E. & Wald & df & Sig. & Exp(B) \\
\cline { 2 - 7 } & Lower & Upper & Lower & Upper & Lower & Upper \\
\hline Product Quality (X1) & 1.237 & .316 & 15.305 & 1 & .000 & 3.447 \\
\hline Price (X2) & -.716 & .310 & 5.325 & 1 & .021 & .489 \\
\hline Income (X3) & 1.374 & .271 & 25.799 & 1 & .000 & 3.952 \\
\hline Halal Labelling (X4) & 1.600 & .292 & 29.956 & 1 & .000 & 4.952 \\
\hline Brand Ambassador (X5) & .608 & .285 & 4.543 & 1 & .033 & 1.837 \\
\hline Constant & -2.212 & .371 & 35.587 & 1 & .000 & .109 \\
\hline
\end{tabular}

Sourse: Processed data, 2020

Источник: обработанные данные, 20202.

Generally, Logistic Model Interpretation can be seen on mathematical equation as follows:

$$
\begin{gathered}
g\left(X_{i}\right)=\frac{e \beta^{0}+\beta_{1} X_{1}+{ }_{2} X_{2}+\cdots+\beta_{k} X_{k}}{1+e \beta^{0}+\beta_{1} X_{1}+\beta_{2} X_{2}+\cdots+\beta_{k} X_{k}} \\
g\left(X_{i}\right)=\frac{\pi\left(X_{1}\right)}{1-\pi\left(X_{1}\right)}=e \beta_{0}+\beta_{1} X_{1}+\beta_{2} X_{2}+\beta_{k} X_{k} \\
g\left(X_{i}\right)=\operatorname{Ln} \frac{\pi\left(x_{1}\right)}{1-\pi\left(X_{i}\right)}=\beta^{0}+\beta^{1} X^{1}+ \\
+\beta^{2} X^{2} \ldots+\beta_{k} X_{k} \\
g\left(X_{i}\right)= \\
=e \frac{\left(2,212-1,237 X_{1}+0,716 X_{2}-\right.}{1+e\left(\left(2,212-1,237 X_{1}+0,716 X_{2}-\right.\right.}
\end{gathered}
$$

$$
\begin{gathered}
\frac{\left.-1,374 X_{3}-1,600 X_{4}-0,608 X_{5}\right)}{\left.-1,374 X_{3}-1,600 X_{4}-0,608 X_{5}\right)} \\
g\left(X_{i}\right)=\frac{\pi\left(X_{\mathrm{i}}\right)}{1-\pi\left(X_{\mathrm{i}}\right)}= \\
=\left(2,212-1,237 X^{1}+0,716 X^{2}+1,374 X^{3}+\right. \\
\left.+1,600 X^{4}+0,608 X^{5}\right) \\
g\left(X_{i}\right)=\operatorname{Ln} \frac{\pi\left(X_{\mathrm{i}}\right)}{1-\pi\left(X_{\mathrm{i}}\right)}= \\
=2,212-1,237 X^{1}+0,716 X^{2}+1,374 X^{3}+ \\
+1,600 X^{4}+0,608 X^{5}
\end{gathered}
$$

Generally, the model can be interpreted as follows:

1. The product quality has a significant impact with negative slope for the purchasing decision of the 
beauty product, it is shown by Wald Statistics Value as much as 15,305 with the probability value sig as much as 0,000 while Chi Square Value $(X 2(1, \alpha)=3,8414$. Based on the provision $\alpha$ $=0,05$, so, statistics value $W>(X 2)(1, \alpha)$ and value $\operatorname{sig}(0,000<0,05)$, so, it can be concluded that the product quality variable significantly with positive slope for the decision of the beauty product purchase significantly as much as 5 percent $(5 \%)$. "Valur of Odss Ratio as much as 3,477 means the product quality will have the choosing probability of the good product quality as much as 3,477 times if compared with choosing the bad product quality".

2. The price has a significant impact with negative slope for the purchasing decision of the beauty product it is shown by Wald Statistics Value as much as 5,325 with the probability value sig as much as 0,000 while Chi Square Value $(X 2(1, \alpha)$ $=3,8414$ and value sig $(0,000<0,05)$, so, it can be concluded that the price variable can affect the decision of the beauty product purchase significantly in the significance level as much as 5 percent $(5 \%)$. Value of Odds Ratio as much as 0,409 means a low price has a choosing probability of the beauty product as much as 0,489 times if compared with the price of the expensive beauty product.

3. The income can affect the decision of the beauty product purchase significantly, it is shown by Wald Statistics Value as much as 25,799 with the probability value sig as much as 0,021 while Chi Square Value $(X 2(1, \alpha)=3,8414$. Based on the provision $\alpha=0,05$, so, statistics value $\mathrm{W}>$ $(X 2(1, \alpha)$ and sig value $(0,021<0,05)$. So, it can be concluded that the income variable has a significant impact of the purchasing decision of the beauty product with odds ratio as much as 3,952 , it means that the income has a decision probability of the beauty product as much as 3,952 times if compared with the price. It shows that the income has the most dominant impact after the price variable as factors which have the purchasing decision of the beauty product. It means that customers care the income which is gotten to be spent to buy the cosmetics product.

4. The halal labeling has a significant impact and positive slope for the purchasing decision of the beauty product. It is shown by Wald Statistics Value as much as 29,956 with sig probability value as much as 0,000 while Chi Square Value $(X 2(1, \alpha)=3,8414$. Based on the provision $\alpha=$ 0,05 , thus, statistics value $W>(X 2(1, \alpha)$ and sig value $(0,000<0,05)$, so, it can be concluded that Halal Labeling Variable has a significant influence with positive slope for the purchasing decision of the beauty product on the significance level as much as 5 percent (5\%). Value of Odds Ratio is 3,952 , it means that the halal labeling is going to own the choosing probability of the beauty product which has the halal labeling as much as 3,952 times if compared with choosing the beauty product without the halal labeling.

5. Brand Ambassador has a significant influence and positive slope for a purchasing decision of the beauty product to buy it. It is shown by Wald Statistics Value as much as 4,543 with sig value as much as 0,033 , while Chi Square Value $(X 2(1, \alpha)$ $=3,8414$. "Based on the provision $\alpha=0,05$, so, statistics value $W(X 2(1, \alpha)$ and sig value $(0,033$ $<0,05)$, thus, it can be concluded that brand ambassador variable has significant influence for a purchasing decision of the beauty product on the significance level as much as 5 percent (5\%). Value of Odds Ratio as much as 0,109, it means that brand ambassador will have a probability in choosing the beauty product with passion in brand ambassador as much as 0,109 times if compared in choosing passion of brand ambassador which is not suitable with the consumers' passion.

\section{Economic Analysis}

1. The Product Quality Influence on the Purchasing Decision of the Halal Cosmetics Product

The estimation result shows that product quality gives contribution for a purchasing decision of the beauty product. It means that a product quality is very important. The good product quality shows that the product is proper to be consumed by the consumers. One of good beauty product characteristics is owning a spreading license from BPOM, halal labeling, clear composition, and ingredients used is undangerous for a long time.

Consistent research which was carried out by (Hong et al., 2019) found that quality product had significant influence of purchasing decision of the halal beauty product. Contrast (Abd Rahman et al., 2015) in his research stated that product quality without significant influence also will have positive direction for purchasing decision of the halal cosmetics product which is supported by religiosity indicator.

\section{Influence of Price for Purchasing Decision of Halal Cosmetics Product}

Estimation in this research finds that price has negative correlation for the purchasing decision of the beauty product; it means that the price has contribution for a purchasing decision of the beauty product. Generally, the price has an important role in taking a purchasing decision of the beauty product. The high price will lower consumers' passion for the product, but if the price of the cosmetics will make the 
consumers thinking many times to buy the product. Nevertheless, there are still some consumers who don't care about the price, the high price or the low price of the beauty product are not their problem, they prioritize the quality product, if the product is good and suitable with their skin, they keep buying it to make their appearance will be interesting.

It is suitable with the consistent research by (Hong et al., 2019) about the details of the consumers' attitude in determining the halal product purchase. There is an positive and significant aspect namely competitive price, income, availability of the product and trusted halal certification. It is contrast with a research carried out by (Shahid et al., 2018; Abd Rahman et al., 2015) which found that the halal product selecting ignored the price and the income as the predictor variable.

3. The Income Impact for the Purchasing Decision of the Halal Cosmetics Product

This study finds that the income has a positive and significant impact for the purchasing decision of the beauty product. This result is similar with the research (Hong et al.,; Anam et al., 2018) which finds that price, education and income have the significant positive impact of the purchasing intention for the Islamic beauty product.

It means that the income is one of the factors which has a tight impact in the consumers' decision to buy a beauty product which is usually consumed by them. After the researchers carried out a research with the respondents, finally, they found that the income which is gotten by them, they always put aside for the beauty necessary, not only the cosmetics product but also the other body treatment such as going to the beauty clinic. The price and the income are main factors affecting the purchasing decision of the beauty product. Some of the respondents have opinion that the high price is not a problem to buy the product. Nevertheless, other some of the respondents have opinion that they just buy it which depends on their budget and monthly needs.

4. The Halal Labeling Impact for the Purchasing Decision of the Halal Cosmetics Product

This research proved that the halal labeling has positive and significant impact for the purchasing decision of the beauty product. The halal labeling is a factor which becomes the consumers' decision in buying the beauty product. Consistent with the research (Anam et al., 2018; Shahid et al., 2018; Abd Rahman et al., 2015) found that the halal labeling has a significant correlation for the purchasing decision of the Islamic beauty product. It proves that the availability of the halal label on the cosmetics product has given a positive value which has a great opportunity in affecting the purchasing decision of the beauty product.

Every consumer who wants to buy the beauty product, the first thing which is seen by the consumers is the halal labeling on the beauty product wrap, but there are also some of the consumers who don't care the halal labeling on the beauty product they use. Consumers have a reason that the halal labeling on the product does not secure that the product is really halal. There are also some of the consumers who have opinion that they stay buying the products without the halal labeling on the package because the product suits their skin.

Nevertheless, there are still many respondents who really care the halal labeling on the beauty product they use. It is contrast with the respondents who don't really care the halal labeling, the selective respondents really care the halal labeling on the beauty product, they have opinion that if the beauty products have the halal labeling, it means that the products have license and certificate from Majelis Ulama Indonesia (MUI) and it is obvious that they can ensure that the product contains halal ingredients and it is safe to consume in a long term. At last, the consumers don't need to be worried about the product. The halal certificate is a written statement from MUI which states that the product is halal based on Islamic Sharia. The halal certificate is main requirement to attach the halal labeling. The halal labeling and the certificate have purpose to give the legal certainty and the consumer's protection.

5. The Impact of Brand Ambassador for the Purchasing Decision of the Halal Cosmetics Product

The analysis result and the estimation show that Brand Ambassador has significant value and positive slope. Consistent with Halal (Jamshidi \& Hussin, 2016) states Moslems responded negative in buying the halal product. It means that brand ambassador has its own impact for consumers to buy and trust on the beauty product. Meanwhile, the result with negative slope means that not all consumers will be interested with brand ambassador which is contracted by the beauty product. They trust the result on their skin, because some of the consumers don't really know about what the contracted brand ambassador by the beauty company. Brand Ambassador is a contracted artist by the beauty company to attract consumers to buy the beauty product they sell.

Nevertheless, some researches reveal that most of the consumers are affected by the halal marketing and the branding practice because affected by the 
sale promotion and the celebrities' support (brand ambassador) (Amin et al., 2014). Consistent with it, Islamic Branding is positively responded significantly but it should be monitored and it needs to improve the Islamic Brand Promotion, it has purpose to affect consumers' interest significantly in buying the halal product (Mohd Yusof \& Wan Jusob, 2014).

\section{Conclusion}

Based on the survey at 18 districts (kecamatan) in Palembang city. This paper observes the main determining factors which affect the purchasing decision of the halal product especially on the beauty product cosmetics in Palembang city. The findings confirm that Moslems in Palembang city have the high concern level on the low halal products, especially the beauty products. Overall, there are five potential factors which affect the purchase of the halal beauty product. Four variables have positive effects such as product quality, income, halal labeling, and brand ambassador. Meanwhile, the price has negative and significant impact for the purchasing decision of the halal product. Generally, Moslems in Palembang city don't place the Islamic demand aspect, nevertheless, based on aspect from its price. It means that the religiosity and the awareness improvement of the halal product is important or it has a role as influencer to consume the product. This phenomenon occurs because of the education and the knowledge of the halal product is high relatively. This important aspect should be attention in the cosmetics halal purchase, because it is not only about the price but also the religiosity aspect such as knowledge, attitude, Islamic brand and subjective norm before deciding to buy the product.

\section{References}

1. Abd Rahman A., Asrarhaghighi E., Ab Rahman S. Consumers and halal cosmetic products: Knowledge, religiosity, attitude and intention. Journal of Islamic Marketing. 2015; 6(1):148-163. https://doi. org/10.1 108/JIMA-09-2013-0068

2. Amin H., Abdul-Rahman A. R., Razak D.A. Theory of Islamic consumer behaviour: An empirical study of consumer behaviour of Islamic mortgage in Malaysia. Journal of Islamic Marketing. 2014; 5(2):273-301. https://doi.org/10.1108/JIMA-06-2013-0042

3. Anam J., Sany Sanuri B.M.M., Ismail B.L.O. Conceptualizing the relation between halal logo, perceived product quality and the role of consumer knowledge. Journal of Islamic Marketing. 2018; 9(4):727-746. https://doi.org/10.1108/JIMA-022017-0019

4. Ansari N. U., Mohammed H. (2015). Factors affecting the intent to purchase halal personal care products: empirical evidence from Pakistan. International Journal of Islamic Marketing and Branding. 2015; 1(2):199. https://doi.org/10.1504/ijimb.2015.071784

5. Ariffin S.K., Ismail I., Shah K.A. Religiosity moderates the relationship between ego-defensive function and attitude towards advertising 1. Journal of Islamic Marketing. 2016; 7(1). https://doi.org/https://doi. org/10.1108/JIMA-11-2014-0074

6. Ashraf M.A. Islamic marketing and consumer behavior toward halal food purchase in Bangladesh: An analysis using SEM. Journal of Islamic Marketing. 2019; 10(3):893-910. https://doi.org/10.1108/JIMA-032018-0051

7. Badan Pusat Statistik Kota Palembang. Palembang Dalam Angka. 2019. URL: https://palembangkota.bps. go.id/publication.html

8. Dinar Standard. State of the Global Islamic Economy Report 2019/20. In Dubai International Financial Centre. 2019. URL: https://haladinar.io/hdn/doc/ report2018.pdf

9. Gujarati D.N. Basic Econometrics. (4th ed.). McGrawHill Companies. 2004.

10. Hong M., Sun S., Beg A.B.M.R., Zhou Z. Determinants of halal purchasing behaviour: evidences from China. Journal of Islamic Marketing. 2019; 10(2):410-425. https://doi.org/10.1 108/JIMA-03-2018-0053

11. Jamshidi D., Hussin N. Forecasting patronage factors of Islamic credit card as a new e-commerce banking service. Journal of Islamic Marketing. 2016; 7(4):378-404. https://doi.org/10.1108/jima-072014-0050

12. Karim A. Ekonomi Mikro Islami (5th ed.). PT Raja Grafindo Persada. 2016.

13. Mohd Yusof Y.L., Wan Jusoh W.J. Islamic Branding: The Understanding and Perception. Procedia-Social and Behavioral Sciences. 2014; 130(May):179-185. https://doi.org/10.1016/i.sbspro.2014.04.022

14. Mukhtar A., Butt M.M. Intention to choose Halal products: The role of religiosity. Journal of Islamic Marketing. 2012; 3(2):108-120. https://doi. org/10.1108/17590831211232519

15. Pew Research Center. The Future of World Religions: Population Growth Projections, 20102050. 2019; (April):1-12. URL: https://www. pewforum.org/2015/04/02/religious-projections$2010-2050 / \% 0$ Ahttps: //www.pewforum. org/2015/04/02/religious-projections-20102050/\#projected-growth-map

16. Salam M.T., Muhamad N., Leong V.S. Measuring religiosity among Muslim consumers: observations and recommendations. Journal of Islamic Marketing. 2019; 10(2):633-652. https://doi.org/10.1108/ JIMA-02-2018-0038

17. Sayogo D.S. Journal of Islamic Marketing. Journal of Islamic Marketing Article. 2018; 4(1):2013-2014. 
18. Shahid S., Ahmed F., Hasan U. (2018). A qualitative investigation into consumption of halal cosmetic products: the evidence from India. Journal of Islamic Marketing. 2018; 9(3):484-503. https://doi. org/10.1108/JIMA-01-2017-0009

19. Taherdoost H. Sampling Methods in Research Methodology; How to Choose a Sampling Technique for Research. SSRN Electronic Journal, January. April 10, 2016. https://doi.org/10.2139/ssrn.3205035

20. Wilson J.A.J. The new wave of transformational Islamic marketing: Reflections and definitions. Journal of Islamic Marketing. 2012; 3(1):5-11. https://doi. org/10.1108/17590831211225436

21. Wilson J.A.J. The "halal" phenomenon: An extension or a new paradigm? Social Business. 2014; 4(3):255-271. https://doi.org/10.1362/20444081 $4 \times 14103454934294$

22. Wilson J.A.J., Liu J. Shaping the Halal into a brand? Journal of Islamic Marketing. 2010; 1(2):107-123. https://doi.org/10.1108/17590831011055851

Submitted 01.06.2020; revised 16.06.2020; published online 30.06.2020

About the authors:

Retno Senjawati, Suhel, Imam Asngari, Faculty Economic, Sriwijaya University, South Sumatera, Indonesia (llir Barat 1, Palembang, South Sumatera, 30128), Senjawatiretno03@gmail.com

All authors have read and approved the final manuscript.

Поступила в редакцию: 01.06.2020; одобрена: 16.06.2020; опубликована онлайн: 30.06 .2020

\section{O6 авторах:}

Ретно Сенджавати, Сухел, Имам Аснгари, экономический факультет, Sriwijaya университет (Sriwijaya University (UNSRI)), Южная Суматра, Индонезия (30128, Южная Суматра, Палембанг, Илир Барат 1), Senjawatiretno03@gmail.com

Авторы прочитали и одобрили окончательный вариант рукописи.

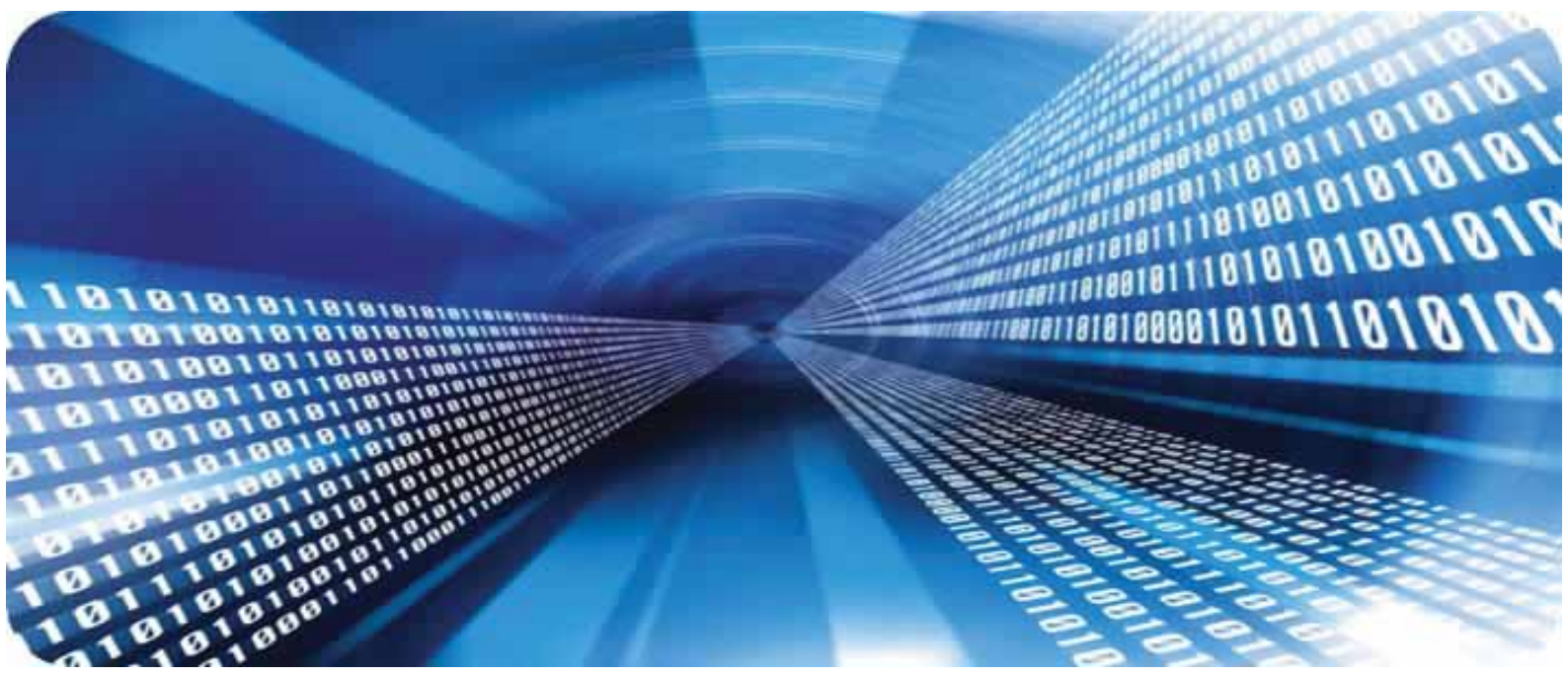

